\title{
Den lige linje \\ i Grundtvigs religiøse udvikling
}

Et essay

af Jakob Rod

\section{Forelskelse}

Når Grundtvig $i$ »Mands Minde« giver latinskolen skylden for at have forvandlet ham til en »kold, lavstammet og selvklog Person« er det kun delvis retfærdigt. Grunden var lagt i forvejen.

Hans følelsesliv, det bedste og stærkeste i ham, havde ikke haft mulighed for at udvikle sig i takt med hans øvrige anlæg.

Følgen var et mindreværdskompleks, der i det meste af hans ungdomstid havde uheldige virkninger på hans forhold til omgivelserne. Folk fandt ham med rette frastødende og usympatisk. Andslivet havde han kun ringe sans for. Barnetroen kastede han over bord.

Tydeligt røber han, hvor uudviklet hans følelsesliv er, når han i Dagbogen beskriver sine »følelser« for det svage køn. Den bestandige ræsonneren for og imod bindende forhold er tragikomisk og udelukker, at der kan have været tale om virkelige forelskelser.

Først da han på Langeland lærer fru Constance Leth at kende, kommer hans følelsesliv i bevægelse. Da sker det til gengæld med stor voldsomhed. Skallen, der skulle gennembrydes, for at følelserne kunne komme frem, var hård.

Fru Constances betydning for Grundtvig skal ikke undervurderes. Dog var det ikke hende, han elskede, men sit eget spejlbillede $i$ hendes letbevægelige og følelsesvarme væsen. Ved at se sig selv $i$ hende opdagede han, at han ikke var det forstandsmenneske, han havde udviklet sig til.

At han samtidig kaster sig over studiet af den tyske romantik, skyldes vel, at han har følt, at der i den romantiske litteratur kunne være et og andet at hente nu, da hans følelsesliv var blevet vakt.

Det ulyksalige var imidlertid, at romantikken førte ham på vildspor, når det gjaldt at finde en løsning på den konflikt, han befandt sig i. Den romantiske flugt fra den barske virkelighed ind i en smuk- 
kere og renere verden kunne umulig blive en akceptabel løsning for Grundtvig, der trods sit digtertemperament havde et særdeles realistisk forhold til det nærværende.

Bekendtskabet med romantikken gør altså blot konflikten yderligere kompliceret. Men netop derfor er dagbogsbladene fra Egeløkke-tiden spændende læsning, ja, dybt gribende dokumenter om et stort menneskes kamp for at komme til rette med sig selv og sin tilværelse.

I næsten hele Egeløkke-tiden vakler han mellem lidenskaben og den romantiske verdensflugt. Kun en enkelt dagbogsoptegnelse fra maj I 806 røber, at han glimtvis har »ahnet« den eneste farbare vej ud af konflikten, den at sondre mellem følelseslivet og dets billede, fru Constance: »Kan jeg bringe det saavidt, da er Jeg reddet; thi da er Jeg hævet over den Lov, der byder Mennesket søge sine Problemers Løsning uden for sig selv«.

Problemet var - sagt på en anden måde - hvordan man kan elske, uden viljesløst at prisgive sig lidenskaben. Det er dette problem, Grundtvig finder løst $\mathrm{i}$ den nordiske mytologis syntese af kærlighed og styrke.

\section{Korlighed}

Allerede digtet »Freis Kærlighed « fra sommeren I8o6 er præget af denne problematik. Kærligheden skildres som en uimodståelig lidenskab. Alligevel fordømmes Frei, fordi han giver efter for sin længsel. Men da Grundtvig - kæmpende mod sin egen lidenskab - selv føler sig ramt af dommen, udpeges til syvende og sidst Loke som den skyldige. Slutningen bliver derved uklar. Men det måtte den jo blive i betragtning af digterens situation.

Under sin beskæftigelse med mytologien kommer Grundtvig selvfølgelig ind på mange andre emner end det erotiske. Men det er påfaldende, så ofte han benytter lejligheden til at reflektere over dette for ham selv så betydningsfulde emne.

I »Om Asalæren« funderer han over »den Besynderlighed, at Maanen (i de nordiske sprog) hører til Han- og Solen til Hunkiønnet, ret som vilde han (nordboen) sige, at det var Quinden, der, som et høiere Væsen beskinnede Manden med sine Straaler, og gav ham sin Glands«. Et nyt kvindeideal er ved at blive til.

I »Maskeradeballet i Danmark« fordømmer han (sin egen) eroti- 
sk(e) vellyst og anviser kvinden den plads, hvor hun ifølge citatet fra »Om Asalæren « hører hjemme: »Men Kvinde, du, som Herren af sin Sol / En Straale gav, for Mandens Bryst at varme / Kys Altrets Fod og sværg ved Straalen selv / At ej med den du mer min Søn vil daare

Og da han i »Nordens Mytologi« fra 1808 konstaterer, at selv de nordiske kæmper kunne føle trang til »at have i Himmelen et ømt kvindeligt Hjerte, der var aabent for deres Udtømmelser«, skynder han sig $\mathrm{i}$ en fodnote at bemærke, at »just det var Nordens høieste Triumf, at dens Sønner i deres høie Trods, knælede for Kærligheds Alter«.

Senere gør han i »Optrin af Kæmpelivets Undergang i Nord « Palnatoke til sit talerør, han, der lukker Jomsborg for kvinder og bestemmer, at kæmperne kun lejlighedsvis må være hos deres mø. Thi - som han siger - »Manddom døer i Kvindens kælne Favn«. Kvinden er fagerst, »naar hun stundom glemmer sin Svaghed, klæder sig i Staal og holder Skjoldet for sin Bejler «.

Dette kvindeideal får kød og blod i Brynhild-skikkelsen i det sidste af periodens skrifter, »Optrin af Norners og Asers Kamp«. Brynhild bliver for Grundtvig symbolet på den syntese af kærlighed og styrke, som han selv stræber at virkeliggøre.

Da han har tilegnet sig dette ideal, har han opnået, hvad han søgte: at blive lidenskaben kvit med følelseslivet i behold. Han har ikke længere brug for dette stof. Det lægges på hylden.

\section{Hovmod}

Nu begik han så den fejl, som mange vist nok begår, når de har gjort et betydeligt fremskridt i menneske- og selvforstålse. Han gav sig selv, sit bevidste Jeg, æren for det. Resultatet blev det sædvanlige: en kunstigt oppustet Jeg-følelse, en selvovervurdering uden grænser.

Dette viser sig især $\mathrm{i}$ to episoder, begge i året I8Io: $\mathrm{I}$. opgøret med forældrene angående spørgsmålet om at blive faderens kapellan, og 2. affæren omkring dimisprædikenen.

Brevene til hjemmet er ganske vist præget af sønlig høflighed, men Grundtvig lægger ikke skjul på, at det er langt under hans værdighed at blive kapellan i Udby. Det vil give »Banen en anden Retning « og betynge med sysler, »der lidet passe for Kristi Tjenere« 
Hvad må den gamle præst i Udby ikke have tænkt! Især da Grundtvig sidst på sommeren meddeler, at han »ikke føler Lyst til at være Præst i Udby«, men i stedet agter at søge det ledige embede i Præstø.

Tydeligst kommer hovmodet og selvovervurderingen dog frem i dimisprædikenen og i affæren efter dens udgivelse.

Selve prædikenen er $\mathrm{i}$ hovedsagen et skånselsløst angreb på samtidens præster, der efter Grundtvigs mening har lempet sig efter tiden $\mathrm{i}$ angst for dens spot. Præsterne tror ganske simpelt ikke på det, de selv siger. Derfor er Herrens ord forsvundet af hans hus.

Dimisprædikenen udkom i maj og blev mødt med protest fra 6 københavnske gejstlige, der indgav en klage til kancelliet.

Grundtvig fattede ikke dette skridt. Et menneske med så overdrevne forestillinger om sit eget værd forstår ikke verdens modstand og manglende lydhørhed. Skuffelsen er tilstrækkelig forklaring på, at forfattervirksomheden ligger stille resten af sommeren.

I efterårsmånederne træder reformatoren $\operatorname{dog}$ frem påny med endnu større kraft og endnu stærkere overbevisning. Han har beskæftiget sig med korstogenes historie og fundet ud af, at middelalderen slet ikke var det mørke tidsrum, som man havde antaget, men tværtimod kristendommens helteperiode, en opfattelse, som han med begejstring gør til sin egen.

Ja, ikke blot det. Han slår sig selv til ridder af korset og opfatter sit kald som det »at virke for den fordærvet Slægts Genfødelse«.

Derfor kan han naturligvis heller ikke møde for konsistorium og modtage en irettesættelse for dimisprædikenen, men må bede kongen om at få sin sag afgjort ved en domstol.

Derefter fremturer han i sine dagdrømme om at spille betydende person, og i fortalen til »Nytaarsnat « får disse drømme deres hidtil markanteste udtryk: »Nedkaste mig i den brusende Strøm, det maa jeg, henrive mig mægter den ej, men om den skal lukke sig over mig, derfor raader den Evige. Paa Randen af det bundløse Svælg - vil jeg stande. - Kalde og varsle i Herrens Navn, det vil jeg, saalænge han forlener mig Kraft og tillader mig at opløfte Røsten«.

Denne tilstand varer til hen mod midten af december, da de stolte drømme pludselig bryder sammen. Grundtvig var på det tidspunkt både syg og overanstrengt. Men den egentlige årsag til sammenbruddet var nok den, at han omsider forstod, at han havde svunget sig op til en position, som der ikke var dækning for hos ham selv. 


\section{Angst}

Når det går op for et menneske, at det har lidt af storhedsvanvid, kan det blive angst for sig selv. I Grundtvigs tilfælde forvandledes angsten til en panisk djævle- og fortabelsesskræk. $\mathrm{Og}$ af denne knibe så han kun een udvej: Flugt over i en eller anden autoritet. Tilflugtsstedet blev bibelen som udtryk for Guds ufejlbarlige åbenbaring og vilje.

Så kastede han sig da med fornyet styrke over bibelstudiet, og alt, hvad han tænkte, sagde og skrev, blev fra nu af præget af bibelske tanker og sentenser.

Men da biblicismen var et angstprodukt, blev Grundvig aldrig bibelteolog. Hans tanker om bibelen fremføres alle vegne i postulatets form med krav om blind underkastelse. Påstande om, at bibelen er Guds ord, Guds sandhed og lignende, findes i hobetal i skrifterne. Og hans forsøg på at omvende andre til hans eget forhold til bibelen kunne antage hysteriske former. Men bibelteologi leder man forgæves efter.

Det falder ham også tungt at være tro mod sine egne fanatiske bekendelser til bibelen, i hvert fald i digtningen, hvor han jo altid er et hestehovede foran sine officielle standpunkter. Dette er $\gg$ Roskilde Rim « et udmærket eksempel på.

Vidste man ikke, at forfatteren til dette digt var den samme, som i andre skrifter udtaler sig særdeles kategorisk om sin kulsviertro på bibelen og om nødvendigheden af at tage bibelen på ordet, ville man ikke tro det.

Ganske vist kan der fremdrages adskillige eksempler på, at Grundtvig i »Roskilde Rim« bruger bibelens ord i god overensstemmelse med sit bibelstandpunkt, ja, at det stundom lykkes ham på overraskende måde at gøre bibelens tale levende og aktuel. Men gennemgående må man sige, at han slår om sig med bibelcitater uden smålig hensyntagen til, hvad ordene betyder i den sammenhæng, hvori de forekommer i bibelen.

Bibelens forjættelser og domsord anvendes på en helt vilkårlig måde. Det er f. eks. højst mærkværdigt, at et menneske med et bibelstandpunkt som Grundtvigs officielle kan søge sin helt ubibelske tro på kristendommens genoplivelse i Norden begrundet $\mathrm{i}$ bibelen. Men det har han ikke svært ved: Rosenkildens vand har sit udspring i Galilæas bæk. Ps. 68 fortolkes som en salme om Kristi op- 
standelse i Norden. Jakobs drøm med forjættelsen, at »det land, du hviler på, giver jeg dig og dit afkom«, overføres uden besvær på ham selv og hans tro på kristendommens genfødelse i Norden. Og ordet fra Mt. 26, 32: »Jeg går forud for jer til Galilæa« stilles i samme formåls tjeneste: »Englen med de samme Ord/Peger altid op mod Nord «.

Stort set disponerer Grundtvig suverænt med Guds indgriben. Det er selvfølgelig Gud selv, der f. eks. har lukket fløjaltertavlen i Roskilde domkirke for de nyfigne, vantro blikke. Han vil også lade Danmarks fjender gå til helvede.

Bibelens domsord anvendes helt efter forgodtbefindende. Profetens (Amos' eller Jeremias') veråb gælder naturligvis rationalismen, hvis skyld det også er, at Kristus, når han kommer igen, ikke finder troen på jorden. Og de mange domsbilleder i Apocalypsen, som Grundtvig har fordybet sig flittigt i, bliver til en sønderknusende dom over tiden.

Dertil kommer, at »Roskilde Rim« er fuld af udtryk, som slet ikke har rod i bibelen. Burde en bibelkristen ikke have undgået udtryk som »at eje Jesu blod i hjertet«, at svinge sig op for at plukke $\gg$ Edens palmer $\ll$ og at vende hu til »de himmelske koraler «? Og hvad med udtryk som »dødningedansen «, »dødens konge« og mange andre? Og hvorfor tyr han til nordiske billeder: Odins ring Drøpner, der hver niende nat avler ni andre, lige så tunge guldringe, anvendt om den fattige kirkes rigdom (iøvrigt et genialt billede), og Ydun med æblerne, der spiller en væsentlig rolle i digtets slutningsafsnit? Hvorfor, når han nu lægger så megen vægt på at være bibelkristen?

Endelig bør også den rolle, som kultiske motiver spiller, fremhæves. Skildringen af Roskilde domkirke er stærkt præget af kultreligiøse synspunkter, og det er tydeligvis Kristi nærværelse i kulten langt mere end bibelens tilstedeværelse, der er grundlaget for digterens stærke håb om en fremtid for kirken.

Det her fremførte befæster det indtryk, at de stærke bekendelser til bibelen som Guds ord og de undertiden hysteriske krav om, at bibelen skal tages på ordet, ikke har rod i Grundtvigs dybere sjæleliv, hvorfra hans digtning fremvælder. Biblicismen virker overfladisk, kunstig og ufordøjet, som en skanse, han skjuler sig bag for at beskytte sig mod en overhængende fare eller en grum forfølger.

Fra denne skanse kunne han så tillige foretage udfald mod fjen- 
den. Hovmodet var nok knust, men reformatordrømmene ikke. De havde kun skiftet subjekt. Før krisen var det Grundtvig selv, der var reformatoren, som skulle redde kirken. $\mathrm{Nu}$ er det Gud i hans åbenbarede ord med Grundtvig som det lydige, men uværdige redskab.

Denne holdning skaffede ham mange uvenner: Molbech, Oehlenschlæger, Mynster, Ørsted, for at nævne nogle af dem, han gerådede i klammeri med. Alle disse stridigheder er i deres forløb karakteristiske for et menneske $\mathrm{i}$ en sådan sindstilstand. Indre svaghed, der bliver til agression.

Et af de mest prægnante udtryk for denne indstilling har vi i Grundtvigs tale ved landemodet i Roskilde i oktober I8ı4, 》Om Polemik og Tolerance eller om Tvist og Taal«. Tolerance er, siger han her, noget, som enhver kristen bør afsky og »mandigen« bekæmpe. Den er udtryk for ligegyldighed for meninger angående »Menneskets høieste Anliggender«. Derfor må han stemple »den Lærdom, som mest monne føres i Kirke og Bog « som »Løgn og Tant«. Dermed er det sagt, det, som bør siges: »Jeg har talt og frelst min Sjæl ... Jeg er reen af eders Blod «.

Talen skaffede ham en alvorlig irettesættelse fra biskop Münter og medførte, at den ene præst efter den anden lukkede sin kirke for den embedsledige kapellan, der ellers siden sin afsked med Udby ofte havde prædiket $\mathrm{i}$ københavnske kirker.

Ved juletid I8I5 tager han da den beslutning, at han ikke oftere vil betræde en københavnsk prædikestol, før han bliver lovligt kaldet til et embede, men i stedet kaster sig over litterært og historisk arbejde.

Ved denne regressive holdning søgte han at afreagere den fiasko, som hævdelsen af stærkt subjektive meninger havde ført ham ud i.

Et brev til oberstløjtnant C. Høegh-Guldberg fra februar I8I6 afspejler tydeligt situationens ejendommelighed. »Inderlig tungt maa det være mig «, siger Grundtvig her, »at tie med, hvad der egentlig ene i sig selv er værd at tale om, og sysle hartad udelukkende med, hvad der kun har relativ Værd og Vigtighed«. Som om han ikke selv havde valgt det!

Typisk er det også, at han føler denne selvvalgte reduktion af personligheden som en slags hævnakt, der giver ham en vis indre fryd, fordi han er overbevist om, at han »i stille Arbejdsomhed i Ting Verden kalder sine « kan »undergrave paa en offentlig og ærlig Maade det Sandhuus, Man ikke kunde taale at see omkastet med en Fart«, 
og fordi han er sikker på, at hans næste arbejder vil blive »ligesaa umaadelig roste, som de forrige ere lastede .

I slutningen af brevet giver han dog udtryk for dyb sorg over, at det er forment ham at prædike Guds ord. Så helt tilfreds med den regressive holdning er han dog ikke. I de følgende år søger han da også, men uden held, adskillige embeder både i København og provinsen.

Den nye holdning medfører heller ikke nogen ændring i forholdet til omverdenen, selv om den i praksis reducerer mulighederne for sammenstød.

Men biblicismen har i hvert fald udspillet sin rolle, selv om den endnu i nogle år er Grundtvigs officielle kristelige standpunkt. Han lider ikke længere under fortabelsesangst og djævleskræk. Han behøver ikke mere en autoritet til at forskanse sig bag.

Derfor kan nu endelig den religiøsitet, der har rod i følelseslivet og baggrund i barnetroen, bryde igennem og komme til sin ret.

Her er vi da ved den lige linje i Grundtvigs religiøse udvikling.

\section{Barnetro}

Biblicismen er et overgangsstandpunkt, som ikke har noget med Grundtvigs religiøse udvikling at gøre. Af natur var han mere anlagt på følelse, oplevelse og erfaring. Hans religiøsitet måtte derfor også være af følelses- eller oplevelsestypen.

Denne religiøsitet var blevet vakt $\mathrm{i}$ hans barndom, men fortrængt sammen med følelseslivet i ungdomsårene.

Udviklingen i årene $1805^{-10}$ bragte imidlertid en frigørelse af følelseslivet, så betingelserne var til stede for, at den oprindelige religiøsitet påny kunne komme til sin ret (den lige linje), selv om den en tid ligesom stilles i skyggen af biblicismen.

Ejendommeligt nok kommer den første gang til orde, hvor man mindst skulle have ventet det, nemlig under krisen i efteråret I 8I 0 .

Grundtvig beskæftiger sig i disse måneder en del med julens kristelige indhold. Flere digte vidner derom. I et af disse, »Julesang«, kommer han det centrale i den kristne jul på nærmeste hold. Digtet er vel egentlig et læredigt, men en af stroferne er af stærkt personlig karakter: »Og, Frelser, naar saamangengang / I Midnatsmulm vi vanke, / Forført af Lysters Trolddomssang, / Forvildet af vor Tan- 
ke, / O, fødes da hos os paa ny! / Forsmaa ej Hjertets ringe Ly! / Tilgiv hver daarlig Tanke! «

Man aner Grundtvigs egen sindstilstand i disse strofer. Men det mest bemærkelsesværdige er dog linjen $\gg \mathrm{O}$, fødes da hos os påny«. Her røber han nemlig, at han omsider har anet, hvad der skal til for at blive et kristent menneske: Kristus må, som han siger, fødes i mennesket, eller: en Kristus må komme mennesket i møde ud af dets eget sjæleliv.

I den første gendigtning af Luthers »Vom Himmel hoch« følger han som Luther selv nøje evangelietraditionen, og det personlige islæt kommer først frem i det sidste vers, hvor vi atter møder tanken om Kristi fødsel i menneskehjertet: »O, kom nu til mig Herre Jesu Krist/En Seng du dig gøre udi mit Bryst/Og hvil dig udi mit Hjertes Skrin / At ei jeg glemmer Velgerning din«. Denne udformning af motivet er dog ikke nær så prægnant som den, vi har $\mathbf{i}$ $\gg$ Julesang $\ll$.

Men Grundtvig arbejder videre med juletankerne, og $\mathrm{i}$ begyndelsen af december gør han de første udkast til digtet »Dejlig er den Himmel blaa«, som han fuldender d. I2. dec., altså inden sammenbruddet.

Dette digt er et af de bedste vidnesbyrd om den religiøsitet, der blev vakt hos Grundtvig, mens han var barn, men fortrængt sammen med følelseslivet, den religiøsitet, som han selv vragede i sin rationalistiske periode, men som atter begynder at gøre sig gældende, da hans hovmod er ved at lide skibbrud.

Hvis man skal tale om et religiøst gennembrud i I8o9-1 I, er det de få, men markante vidnesbyrd om denne barnetro, man skal hæfte sig ved, og ikke biblicismen, der skyldes Grundtvigs skæve menneskelige udvikling.

»Dejlig er den Himmel blaa《 står ikke nær så isoleret, som man undertiden har villet give det udseende af. Tværtimod er Grundtvigs bedste digte fra perioden $1810-15$ digte med motiver fra barnereligiøsiteten.

Tænk f. eks. på det smukke digt »Englesangen for Vuggerne« i »Kvædlinger 1815 « med dets meget personlige skildring af, hvorledes julens kristelige indhold er blevet ham bevidst: »Alt som jeg lytted, og alt som jeg saae / Droges mit Øie og Øre/Hen til en Vugge afsides i Vraa /Underligt var det at høre / . . / Underlig greb mig den hellige Sang / Underlig sank jeg tilbage / Ret som jeg alt havde hørt 
det engang / Tidlig i Barndommens Dage«. Bemærk også den betydningsfulde slutningsstrofe: »Ingen det undes at kige / Ind i Guds Herligheds Rige/Uden han vorder til Barn igjen/Derfor maa Vuggen jer klemme/Til I med Sang og med Bøn/Vil Hosianna istemme / Love den Høiestes Søn«.

Men det er ikke blot i digtene, vi møder det. Selv i »Bibelske Prædikener« findes barnereligiøsiteten bevidnet. Det gælder især prædikenerne til I. juledag I8I3 og til I. søndag efter hellig tre konger I 815 .

I den første, som Grundtvig har kaldt »Den rette Juleglæde«, får vi ganske vist til indledning nogle betragtninger, som må skrives på biblicismens regning.

Men så kommer det: Når vi hører englenes budskab, »da er det som en himmelsk Klarhed opgaar for vort Øie, en Guddomsstraale skyder sig gennem vort Hjerte, varmer, smelter det i hellig Glæde. Og hele sidste del af prædikenen står i barndomsmindernes tegn: »O visselig, den (juleglæden) var der, hellige Spor var der af den for ej saa længe siden, det ved vi, dersom vi opvokste blandt Menigmand, i gammeldags, gudfrygtige Huse, ja, da har vi set mangen Levning af hellig Juleglæde, da har det aabne Barnehjerte delt den, Billedet af hvad vi saa, hvad vi hørte og følte som Børn om Julen, staar da for os, som et Glimt af Paradiset«.

I den anden prædiken taler Grundtvig om dette »barneparadis«, der tidligt, alt for tidligt gik tabt for ham, og siger så: »Vi komme i Hu, hvorledes fromme Mødre lærte os at lægge de smaa Hænder sammen og stamme med Tungen det Navn, som er over alle Navne, i hvilket alle Knæ skal bøje sig, i hvilket der alene er Frelse og Fred. Vi komme da i Hu den Barndommens uanfægtede Tro og den faste Tillid til den Gud, hvis Ansigt vore Engle saa, hvis Engle lejrede sig om vor Vugge og vogtede vore Gange. Vi kom i Hu, med hvilken barnlig Andagt vi mangen Gang tiltalede med Bøn den usynlige Fader, om hvis Nærværelse og Kjærlighed og Magt vi aldrig tvivlede. Vi komme i Hu, med hvilken Glæde vi vare opfyldte paa de hellige Højtider og fornemmelig paa Julens Barnefest, hvor inderlig vi elskede de søde Toner om det lidet Barn saa lysteligt, som kommet var til Jorden, hvor underlig glade vi nynnede med Morten Luther: O, vær velkommen, du ædle Gjæst! Vi komme i Hu, med hvilken barnlig Alvor og Højtidelighed vi ved vore Forældres Haand opgik til Herrens Hus at høre paa de ældres Sang og Ordets Tale; vi kunde 
ej adskille og samle saa, som de opvoksne, men vidste dog, at det var Gud i Himmelen, hvis Lov og Pris blev sjunget, hvis Ord forkyndtes fra den høje Stol, vi kjendte dog det Jesu Frelsernavn, og bøjed vort Hoved mod de ældre, og følte i vort Hjærte, at det var godt at tro paa ham, og Taaren perlede i Øiet, endog vi ikke kunde sige, hvi den randt. Ja, kristne Venner! et saadant Skyggebillede af Jesu Barneliv, med tidlig Gudskundskab, med Tro, med Bøn, med Følelse af Herrens Miskundhed og hellig Glæde, et saadant se vi i vor egen Barndom, hvis den henrandt $\mathrm{i}$ gamle kristelige Huse, og have vi ved Guds Naade bevaret Troen, eller ere vi ved hans underfulde Barmhjertighed udfriede fra Mørkets Magt og oversatte i den Guds enbaarnes Rige, da ved vi, til hvilken Velsignelse paa vore Sjæle de fromme Barnedages Ihukommelse har været«.

Sligt er enestående $\mathrm{i} \gg$ Bibelske Prædikener« og er med til at stadfæste det indtryk, at det er et misgreb at gøre biblicismen til hovedsagen i Grundtvigs »kristelige gennembrud«.

Det var barnetroens vækkelse, der var hans største og bedste udbytte af krisen I 8Iо-I I. Det var han også selv udmærket klar over, hvilket f. eks. fremgår af digtet »Udby Have« fra »Saga Nytaarsgave for I 8 I $2 \ll$.

Ved læsningen af dette digt undrer man sig først og fremmest over den nærmest geniale selvforståelse, Grundtvig her lægger for dagen: »Tit det barnlige forgaar/Mens man end er Barn i Aar «, siger han f. eks. Dette er jo netop, hvad han selv har erfaret, takket være den ensidige dyrkelse af den intellektuelle udvikling. Han er derfor også klar over, at det tabte kun kan genvindes, dersom man på en eller anden måde kan blive barn påny: »Da en Stund maa Saga tie / Hun maa tie, hun maa bie / Til vi vorde Børn igen«.

Gribende skildrer han, hvorledes han gennem ungdomsårene har kæmpet for at tilbageerobre det tabte paradis: »Samme Bøger frem jeg tog / Samme Blade jeg opslog / Samme Stave der jeg saae / Men som blege Lig de laae/Intet rørde, intet vilde/For mit Øie sig afbilde $\ll$.

Men så bryder barnetroen igennem, og »Fangerne udgik med Fryd «: »Brat fornam jeg kendte Lyd / Ordene mig laa paa Tunge / I mig tyktes det at sjunge: / Fra Himlen højt komme vi nu her! / Tonen var saa kendt og kær, / Det ei andet kunde være, / Svare maatte jeg til Løn:/Lov og Tak og evig Ære/Ske dig, o Guds hjerte Søn!« 
Gennembruddet giver ham altså det tabte paradis tilbage. Det, han havde mistet gennem den ensidige ungdomsudvikling, bliver nyt og levende for ham igen.

Personlige minder må også ligge til grund for det smukke digt »Karen Bjørns Minde«i $\gg$ Kvædlinger I8 15 «: » Hør, hvor fromt paa Barneviis / Søn og Daatter mangefold/Sig befale Gud i Vold, / Bede: Gud din Engleskare / Fader og os Smaa bevare! / Ja, forlad os, Fader milde! / Hvad vi gjorde, som var ilde! / Hjælp os, saa vi vorde fromme, / Saa vi i din Himmel komme, / Smile sødt i Englefavn! / Hør du os i Jesu Navn!«

De her fremdragne vidnesbyrd lader sig umulig bringe på een formel med biblicismen. Grundtvigs kristelige standpunkt er i disse år ikke eet standpunkt, men to. Et indre med rod $\mathrm{i}$ barnereligiøsiteten og følelseslivet, som inspirerer ham poetisk (den lige linje). Og et ydre officielt biblicistisk, skarpt markeret udadtil, men gennemhullet indadtil. Dette sidste ansporer ham først og fremmest til polemik.

\section{Voksentro}

Man kan måske også sige det på den måde, at der i Grundtvigs standpunkter udadtil er mange brud og bratte overgange, men at hans indre religiøse udvikling følger en nogenlunde lige linje fra barndommen til den voksne alder.

Det kan og skal ikke benægtes, at biblicismen er et iøjnefaldende træk ved det ansigt, han viser verden i årene 1810-15, ja, helt op i 20 'erne.

Men det er tydeligt, at hans standpunkter udadtil efterhånden kommer $\mathrm{i}$ bedre og bedre overensstemmelse med hans indre udvikling.

Allerede prædikenerne fra Præstø-tiden har et noget andet præg end de øvrige bibelske prædikener. Tonefaldet er roligere, horisonten videre.

Sansen for det menneskelige, som vågnede i Dannevirke-tiden, mærkes tydeligt i disse prædikener: »Herren opvække som af Døde den Følelse i eders Hjerter, at I ere Guds Slægt, han oplyse eders Øjne til at se i eder selv en Lignelse af ham«, hedder det i prædikenen til 2. søndag efter trinitatis I 822.

Man møder heller ikke i disse prædikener den voldsomme pukken på bibelen som Guds ord. Derimod kommer en i Grundtvigs prædikener ny forståelse for betydningen af livet i menigheden til orde: 
»Herrens Stad paa Jorden« er »hans Kirke og Menighed, hvor han alle Dage, indtil Verdens Ende er nærværende med Aand og Ord, med Liv og Kraft og Naade«, forkyndes det i prædikenen til I9. søndag efter trinitatis $\mathrm{I} 822$.

Fremhævelsen af disse træk sker ikke for at afdisputere det islæt af biblicisme, der vitterlig også findes i disse prædikener, men for at påpege, at der åbenbart er foregået en udvikling hen mod en mere personlig og menighedsorienteret religiøsitet. Denne udvikling spores endnu tydeligere i prædikenerne fra Vor Frelsers Kirke.

Det er denne religiøsitet, der får et kraftigt frembrud i slutningen af 1823 , da Grundtvig under forberedelsen af sin prædiken til I. søndag i advent læste Romerbrevets ord, at »natten er forbigangen, og dagen er kommet nær«, og det pludselig »gennemlynede« ham, at disse ord er virkelighed. Hovedtanken i prædikenen er da også den, at lyset, som ved Jesu fødsel kom til jord, nu skinner ind i mørket, og at al sand oplysning er Helligåndens gerning.

Det bedste indtryk af, hvor indgribende oplivelsen i december I823 var for Grundtvig får man utvivlsomt gennem det storladne, men i mange henseender dunkle digt »Nyaars-Morgen«, som med rette er blevet kaldt Grundtvigs »hjertekvad «.

Digtet er skrevet om sommeren efter den religiøse oplevelse i december. Men hvorfor skulle det blive sommer, før han kunne skildre det, han havde oplevet, i et digt? Velsagtens fordi den danske sommer med dens grøde, vækst og varme skulle låne hans digtersprog de billeder, uden hvilke han ikke formåede at give udtryk for det nye åndens liv.

Dette stemmer udmærket med, at Grundtvig som pinsens digter i rigt mål gør brug af billeder af den danske sommer. Som solens varme bringer fornyelse til livet i naturen, bringer Helligånden fornyelse til den kristne religiøsitet.

Der kan her være anledning til at henlede opmærksomheden på den svenske religionspsykolog $\mathrm{Hj}$. Sundén's teori, at det nok er det antike billede af solkvinden med det guddommelige barn som livsfornyeren, hvis bevidstgørelse har formidlet forbindelsen mellem naturfølelse og kristendom hos Grundtvig.

Denne teori kunne være forklaringen på visse mærkværdigheder i Grundtvigs tidligere digtning. Hvordan kan det f. eks. være, at løvhyttefesten dukker op i julesalmen »Det kimer nu til Julefest «: »I Bethlehem er Christus fød/Den Frelser-Mand fra Synd og Død/ 
$\mathrm{Nu}$ kom den store Løvsalsfest / Nu blev Jehovah Hyttens Gæst «?

Ved at lade Jesu fødsel indvarsle en løvsalsfest, synes Grundtvig at ville forkynde Jesus som livsfornyeren. Hans Jesusforkyndelse får derved tilknytning til de af Sundén omtalte ældgamle mytologiske forestillinger. I overensstemmelse hermed hedder det i den $2 \mathrm{I}$. strofe af førnævnte salme: »Ja, fryd dig Mark! siung høit, du Skov! I Muldet gaar nu Herrens Plov / Og selv han lægger Sæd i Jord / Til Himmel-Brød paa Alter-Bord «.

Et omtrent samtidigt fragment i heksametre (som f. eks. Hesiods Teogoni) om Rhodos, solguden Helios' ø, kunne tyde på, at Grundtvig netop på dette tidspunkt har ladet sig inspirere af græske teogoni-spekulationer.

Også et fragment af et påskedigt fra ca. I820 må ses i denne sammenhæng. Det hedder heri om Kristus: »Østen og Norden / Alting er hans / Som over Jorden / Breder sin Glands / Dag er hvor han er til Stede / Lys er hans Klæde / Sømmen er skiær«. Det mytologiske islæt er her umiskendeligt.

Det må derfor være naturligt, om man under læsningen af $\gg \mathrm{Ny}$ aars-Morgen « retter opmærksomheden mod det spørgsmål, om det samme motiv genfindes her, og i bekræftende fald hvilken betydning det da har.

Først må man nok slå fast, at man jo ikke kan forvente, at Grundtvig bevidst skal have sigtet mod at udmønte det antike billede digterisk. Der kan højst være tale om, at billedet ubevidst har inspireret ham under udformningen af denne specielle kombination af kristendom og naturfølelse, som er karakteristisk for »Nyaars-Morgen«, men som man genfinder mange andre steder hos Grundtvig.

Alligevel efterlader selv en ret flygtig gennemlæsning af »NyaarsMorgen« det indtryk, at det vel måtte være muligt rundt om i digtet at samle brikker til et puslespil med et billede af solkvinden og hendes søn som livsfornyeren. Et sådant arbejde ligger dog uden for rammerne af dette essay.

Kun skal det antydes, at alene titelen »Nyaars-Morgen « sammenholdt med digtets indhold unægtelig leder tanken hen på antike frugtbarhedsreligioner, hvor nytåret netop falder sammen med vår og sommer.

Ovenfor er der gjort opmærksom på, at Grundtvig f. eks. i »Det kimer nu til Julefest « har ladet Jesu fødsel indvarsle en løvsalsfest. Ganske interessant er det $\mathrm{i}$ denne forbindelse at vide, at man i den 
føreksilske jødedom netop fejrede nytåret sammen med løvsalsfesten (Jvf. Johs. Pedersen: Israel II).

Hvad enten nu Sundén har ret i sin teori eller ej, fremgår det i hvert fald tydeligt af »Nyaars-Morgen «, at kombinationen af Kristus-tro og naturfølelse har ført Grundtvig frem til en opfattelse af Kristus som den, der ikke blot bringer lys, men varme og dermed vækst og frodighed (lys uden varme er helvedes kval). Det er meget nær ved, at kristendommen i »Nyaars-Morgen « fremstilles som en frugtbarhedsreligion.

I overensstemmelse hermed har ordet fred i »Nyaars-Morgen « en næsten gammeltestamentlig klang. For de gamle israeliter var fred jo ikke bare ro, men sjælens helhed, sejr, kraft, liv, sundhed, frugtbarhed og harmoni. En tilsvarende betydning har ordet i »Nyaars-Morgen «: »Mens Markerne bølge/Med staaende Korn/Mens Fuglene følge / Det gamle Skov-Horn / Mens Krøniken rækkes/Og tækkes de smaa / Om Dagen end stækkes / Og Slæderne gaae- / Syng lavt over Skoven / Syng høit over Voven: / Guds Fred over Folket i Nord /

Det frembrud af religiøsitet, som Grundtvig oplevede i $1823^{-24}$, mistede dog ret hurtigt sin styrke. Herom vidner stagnationen $\mathrm{i}$ den poetiske produktion og dennes mangel på kvalitet. Tanken om Kristus som livsfornyeren dukker ganske vist op flere steder i digte og salmer fra tiden $1824-32$, vel også som noget centralt, men dog som noget, der ikke rigtig kommer til sin ret.

I digtet »Korsbanneret « går tanken fremad mod den dag, da »Jorden skal igjen opstande / Reen, forklaret, eviggrøn«. Flere steder strejfes også løvsalsmotivet, f. eks. i »Tør end nogen ihukomme«: $\gg$ Ei skal Zions Borg sig høine/Denne Gang med Spir og Taarn, Hyttelavt i Verdens Øine / Bygges nu imod tilforn « ...»Vi af bløde Bøge-Stammer / Under Nattergale-Sang / Bygge kun et Giæstekammer / Til en himmelsk Alter-Gang « ... »Han, som laae i KrybbeRummet / Bryde vil i Hytten Brød «.

Også i et forsøg på en pinsesalme, der dog tydeligt røber, at Grundtvig endnu ikke er blevet pinsens digter, findes løvsalsmotivet: »Saalænge under Hyttetag / End helligholdes Pindsedag «.

Bemærkes må det også, at englesangen om gudebarnets fødsel nu bliver til en spådom om vækst og grøde: »Trods klingrende Frost, godt Aar I spaae / For Fugl og Sæd i Dvale«.

Samme motiv dukker op i Dagvisen, hvor Jesus er lyset, »som Jordens Bold skal lysne udi og gløde«. Han skal dog ikke blot bringe 
lys, men også varme, så vi må takke Gud for »Alt hvad paa Mark i tusind Aar / Der groed til Sjæle-Føde!« I samme salme har vi det mytologiske motiv »med Straler i Krands om Tinde«, som stammer fra Helios-myten.

I sit forsøg på at kombinere skabelsesmotivet med tanken om Kristus som livsfornyeren begynder Grundtvig nu også at digte om skabelsen. Men med sit danske Tedeum opnår han kun at begå vandalisme mod Brorsons »Op al den Ting ... «, og de øvrige skabelsesdigte er lidet eller intet bevendt.

Forklaringen på denne armod er uden tvivl, at Grundtvig, samtidig med at det nye bryder frem hos ham, tvinges ind i det endelige opgør med resterne af biblicismen, der har udspillet sin rolle, og nødes til at finde en formulering af og en kanaliseringsmulighed for bärnetroen, der nu er det stærkeste hos ham.

Barnetroen må blive til voksentro uden derved at miste sin forbindelse med følelseslivet. Resultatet af denne »pubertetskrise« bliver, at barnetroen efterhånden antager karakter af kultkristendom. I »Kirkens Gienmæle « fra I825 er denne proces fuldbyrdet.

Når Grundtvig her betegner Clausens kirke som et »selv-gjort Luft-Kastel« rammer han dermed ikke blot Clausens kirkebegreb, men ethvert kirkebegreb skabt af en formalistisk autoritetstro, hvad enten den kalder sig bibelsk, luthersk eller rationalistisk.

Mod dette luftkastel sætter Grundtvig »den eneste sande, almindelige (catholske) kristelige Kirke, som ene hviler paa det historiske Fundament «. Denne kirke hviler på en tro og på en bekendelse, som har »Millioners Erfaring, og et vidunderligt historisk Vidnesbyrd for sig «.

Trosbekendelsen, som således efter mange tilløb i de forudgående skrifter her for første gang placeres centralt i kirkens liv, fremstilles ikke som et læresymbol, men som et symbol, der har en bestemt funktion i kirkens liv, nemlig som det, hvorved der indlemmes og udelukkes.

Havde Grundtvig lagt vægt på trosbekendelsens betydning som læresymbol, ville han utvivlsomt have fremhævet dens oldkirkelige betydning som sådan. Nu vælger han det udtryk, at »den har ligget den kristelige Menighed paa Tunge, fra det første Øieblik den oplod sin Mund «, hvorved det fremhæves, at den fra begyndelsen har været et levende kultord, hvorved menigheden gennem alle tider og på alle sprog har forkyndt troen på Jesus Kristus. 
At det er kirkens kultiske funktioner og deres betydning for kristenlivet, Grundtvig har fået øje på, fremgår måske allerklarest af hans ord om, at de kristne nu må trække sig tilbage til koret: »Sandelig det er paa høie Tid, at vi alle, saamange som end i Aand og Sandhed vil være Kristne, forener os om ene at bygge paa den Klippe, der gennem Tidens Løb har trodset de flyvende Storme og brusende Bølger, indskrænke os som Troes-Samfund: som Kirke, til Krybben i Bethlehem, som Historien lærer, lader sig sejrrig forsvare mod Alverdens og Helvedes Magt, at vi, saa at sige, trække os tilbage til Koret, række hinanden, og alle de i Herren hensovne Kristne, Haand over Daaben, og Mund for Alteret, i det ene Brød og den ene Kalk, lade, som Brødre, al Kiv om det tvivlsomme fare, og, ere vi stærke, da ej misbruge vor Magt til at bebyrde de afmægtige, men til at bære deres Skrøbeligheder «.

Her i koret, ved døbefont og nadverbord, må også bibelen finde sin plads. Den skal forstås efter trosbekendelsen og bruges som en opbyggelig og oplysende bog for alle kristne. Og vil de skriftkloge kives med hinanden om bibelens rette fortolkning, må det ske i »skolen«, ikke i kirken.

Opgøret med biblicismen fører nu også til, at Grundtvig må vende sig mod reformatorerne, der »vitterlig eller uvitterlig « lagde grunden til det »exegetiske Pavedom, under hvilket nu den hele kristne Menighed sukker«. Den protestantiske bogreligion må bekæmpes, fordi den fortrænger den personlige religiøsitet og umulig kan eksistere side om side med denne.

»Kirkens Gienmæle« viser, at Grundtvig nu endelig er nået frem til en kristendomsforståelse og -praksis, som kan »bære« den religiøsitet, der siden hans barndom og navnlig siden efteråret i 8 I $о$ havde kæmpet for sin ret til at være enerådende $i$ hans bevidsthed.

Spørgsmålet er imidlertid, om han så også formåede at fastholde dette nye, eller det efterhånden forvandledes til en ny formalistisk autoritetstro, hvori trosbekendelsen kom til at indtage den plads, som bibelen tidligere havde udfyldt. I så fald måtte det vise sig derved, at trosbekendelsen efterhånden $\mathrm{i}$ hans opfattelse forvandledes fra et kultsymbol til et læresymbol.

Nægtes kan det ikke, at selv om Grundtvig til det sidste forstod og brugte trosbekendelsen som kultsymbol, så lå det snublende nær, at det nye standpunkt kunne forvandles til en formalistisk autoritetstro. Det ligger sådan set allerede deri, at Grundtvig vil bruge den 
som eksegetisk norm. Det kan man ikke uden at lægge vægt på dens læremæssige indhold.

Et andet forhold, som kunne fremme og normalt ville fremme tendensen til at betragte trosbekendelsen som læresymbol, er dette, at Grundtvig omgående inddrager sit nye syn på trosbekendelsen i sit apologetiske arbejde. Apologetik fremmer altid tendensen til formalisme.

Derimod var det jo uomgængeligt nødvendigt at søge det nye syn bearbejdet teologisk, hvilket også skete $\mathrm{i}$ afhandlingerne $\gg \mathrm{Om}$ den sande Christendom《 og »Om Christendommens Sandhed «.

Disse afhandlinger vidner om, at Grundtvig selv har anet faren for, at det nye syn kunne udvikle sig til en formalistisk autoritetstro. Noget tilsvarende kan siges om de utrykte udkast til en dogmatisk formulering af kirkebegrebet fra $1827-28$, som $\mathrm{H}$. Høirup gør rede for i sin disputats.

I et af disse understreges det dog med eftertryk, at trosbekendelsen netop ikke er et læresymbol, en skriftlig læreautoritet, men et kultsymbol: »Dette Ord nu, som skal være Troes-Regel, maa være en almindelig Troes-Bekiendelse, og altsaa være Samfundets Medlemmer bekiendt, som Udtrykket for Indholdet af den fælles Tro, og Bekiendtgørelsen kan kun ske paa en af tre Maader: enten ved en fortløbende umiddelbar Aabenbaring til Enhver især, eller ved en mundtlig Meddelelse, eller ved en skriftlig Betegnelse. Da nu enhver Troende ligesaagodt ved at bekiende sin Tro, kan giøre andre bekiendt med dens Indhold, som det kunde ske ved en Engel fra Himmelen, og da derimod enhver skriftlig Betegnelse er i sig selv et dødt Bogstav, kan der vel ikke tvivles om, hvilket Middel der var Gud værdigt, men hvilket der saa end brugdes, maatte Samfundet dog, for at være kiendeligt i Verden virkelig og levende, altsaa mundtlig bekiende sin Tro«.

Det, der lægges vægt på her, er altså trosbekendelsens mundtlige brug i menigheden og dens videreførelse fra slægt til slægt ved gudstjenesten.

Imidlertid begynder Grundtvig snart efter at arbejde med problemet om trosbekendelsens nøjagtige overlevering. Dermed kunde faren for en ny formalisme synes akut.

Hertil bemærker H. Høirup træffende: »Den i sig selv dogmatisk holdbare Position: at Kirkens Trosenhed maa lægge sig »kendelig « og »uforanderlig « for Dagen ved de Handlinger, hvorved Kirken 
konstitueres, bliver nemlig uholdbar i samme Øjeblik som denne kristne Troskerne, denne Bekendelse til »Kirkens Christus«, af Grundtvig haandfast og historisk identificeres med den apostolske Bekendelses Bogstav og i samme Grad som Teorien om Apostolicums historiske Tilblivelse gøres til Borgen for dens Gyldighed «.

Selv om Høirup ganske givet har ret i denne betragtning, må det afgørende dog nok være, at Grundtvig aldrig søger at bevise den apostolske trosbekendelses »ægthed « skriftteologisk eller dogmatisk, men gennem det »økumeniske « bevis og »kraftbeviset«. Heraf fremgår det nemlig, at han lægger vægt på at fastholde trosbekendelsens karakter af kultord, hvis ægthed intet teologisk bevis, men kun dets gennem tiderne uløselige tilknytning til menighedens gudstjeneste kan godtgøre.

Det er vanskeligt at se, at der på noget tidspunkt skulle være sket en ændring i denne holdning. Når H. Høirup derfor konkluderer: at »for vor Undersøgelse har den her behandlede Ms-gruppe sin Betydning ved at godtgøre, hvor hurtigt Dogmatiseringsprocessen sætter ind «, må man nok hertil bemærke, at dogmatiseringsprocessen i dette tilfælde jo ikke består i, at trosbekendelsen fra oprindelig at være opfattet som et kultsymbol nu opfattes som et læresymbol, men deri, at dens stilling som kultsymbol gøres til genstand for dogmatiske overvejelser.

Så længe Grundtvig lægger vægten på, at trosbekendelsen er menighedens mundtlige bekendelse ved dåben, forbliver den så nært knyttet til kulten, at den umulig kan opfattes eller bruges som rent læresymbol.

Heller ikke det at han senere, navnlig fra begyndelsen af 4o'erne lægger stærk vægt på læren om trosbekendelsen som Herrens »mundsord « kan afkræfte dette indtryk. Denne lære, om hvis historiske gyldighed Grundtvig aldrig tvivlede, selv om der kan fremføres og er blevet fremført særdeles gode argumenter imod den, kan netop kun med mening opretholdes under forudsætning af en kultisk opfattelse af trosbekendelsen.

Udgangspunktet for den er jo troen på Kristi virkelige nærværelse i menigheden som den, der selv taler sit ord ved døbefont og nadverbord. Han, som er den samme i går og i dag, ja, til evig tid, kan jo ikke sige eet $\mathrm{i}$ dag og noget andet for 2000 år siden. Teorien er altså kultisk sand, uanset hvad der kan indvendes imod den ud fra et historisk synspunkt. 
Grundtvig undgik altså faren for at havne i en ny formalistisk autoritetstro af samme type som biblicismen. Han er nået frem til et officielt standpunkt, som svarede til hans personlige følelses- og oplevelsesprægede religiøsitet, og kan få denne kanaliseret gennem hengivelse til og medleven i den kristne kult.

\section{Selvvirkeliggørelse}

Dermed havde Grundtvig fundet det ståsted, som han i sin indre udvikling mere eller mindre bevidst havde stilet frem imod gennem hele sit liv (den lige linje).

Af de kræfter, der havde drevet ham frem, havde to vist sig at være af særlig betydning. Den ene var hans naturs krav om et religiøst standpunkt, hvor følelseslivet kunne komme til sin ret. Den anden var hans barnetro. Disse to kræfter havde nu fået deres delvis sammenfaldende krav opfyldt.

Fuldbyrdelsen af denne udvikling er tydelig i $183^{2}$, det år, som K. Thaning med rette har peget på som det afgørende i Grundtvigs opgør med sig selv.

Det kæmpemateriale, som Thaning støtter sin bevisførelse på, bekræfter indirekte, at Grundtvig netop i $183^{2}$ er nået frem til den afrunding af personligheden, også i religiøs henseende, som hans udvikling har sigtet frem imod. Grundtvig »har fået sin verden og sin livsførelse bragt i overensstemmelse«. Han »vender tilbage til sin natur, idet han besjæles af sin naturlige ånd, de nordiske myters ånd Han »bliver sig mere og mere bevidst at leve $\mathrm{i}$ alderdommen, $\mathrm{i}$ forstandstiden «. »Nu har han fundet sin plads over for det liv, der een gang er skabt, og den ånd, der var før os«. Han opgiver »sin himmelstorm og sine dermed sammenhængende forsøg på at moralisere og lave verden om«. Han »bliver frit og bevidst »Hedning«, finder tilbage til sin natur «. Han »overskuer sit eget liv og ser det i sammenhæng, ser det som en udvikling fra ungdom, gennem manddom, til den alderdom, der fra en anden side set bliver en nytårstid «, og $\gg$ bag den nye fredsommelighed, den borgerlige solidaritetsfølelse, det frihedssyn, han selv føler som nyt ... mærker man den ændring i hans personlige liv, som har givet ham nyt lys«. Omvendelsen er en omvendelse fra »fortiden til nutiden, fra de døde til de levende, fra skygge til virkelighed, fra romantik til realisme, fra hans egen ideverden til den foreliggende verden«. 
Det er en fuldt modnet personlighed, der skildres i disse håndplukkede citater fra Thanings disputats, afrundet og fri for indre konflikter. Det, der er sket med Grundtvig, er, at årsagen til alle de mange ligevægtsforstyrrelser, der prægede hans tidligere liv, spændingen mellem de ydre og de indre krav til hans personlighed, er forsvundet.

Dette er, hvad man i den analytiske psykologi forstår ved selvvirkeliggørelse. Selvet, som er den samlede psykes midtpunkt i modsætning til det bevidste Jeg og det ubevidstes skjulte kræfter, har overtaget føringen i personligheden.

Dette betyder ikke blot, at den ustandselige forskydning af det psykiske tyngdepunkt fra det bevidste til det ubevidste sjæleliv og omvendt ophører, men at der indtræder en helt forandret livsindstilling, en total forvandling, der ganske nøje svarer til Thanings skildring af Grundtvig efter 1832 .

Thaning påviser, hvorledes denne nye indstilling ændrer Grundtvigs holdning på så at sige alle områder. I »Haandbog i VerdensHistorien « 1833 bryder et sekulariseret historiesyn igennem og overvinder den tidligere mosaisk-kirkelige anskuelse, der »som ledetråd virker som et specielt kirkeligt synspunkt «, som ikke længere kan bruges. Stillingtagen afløses af »Upartiskhed«, romantik af realisme, og Grundtvig går nu positivt ind for det menneskelige, borgerlige, politiske livs selvstændige betydning.

Omvendelsen sætter sig også spor i hans forkyndelse, salmesang og teologi. I prædikenerne vender han sig mod sine lutherske fædres bodskristendom »og derigennem mod sig selv«. Kampen mod rationalismen træder stærkt tilbage, og opgøret former sig »roligt og sagligt, ikke patetisk og stormende « som tidligere. Hvad indholdet af hans forkyndelse angår, er det vigtigste den ændring, der indtræder i hans forkyndelse af kors og opstandelse. I langfredagsprædikenen til 1832 er »korsfarertonen « forsvundet, og prædikenen er snarest en opstandelsesprædiken, jvf. det af Thaning ofte citerede motto fra Sangværket: »Derfor ingen Korset gribe, før med Herren han opstod «. Forsoningen er ikke længere hans forkyndelses problem; thi »da jorden blev jord, og himlen himmel, gik evangeliets lys op for Grundtvig, og den lutherske bodskristendoms grundord, forsoningen, afløstes nu sædvanligvis i Grundtvigs forkyndelse af ordet forløsning eller genløsning, som opstandelsen er en bekræftelse på.«

Klaringen sætter sig også spor i Grundtvigs salmedigtning. Herom 
siger Thaning: »Det er evangeliets nutidighed, der er det nye i Grundtvigs salmedigtning - også for ham selv. Når han ser fremad, sker det efter salmegennembruddet ud fra troen på, at vi er gået over fra døden til livet. Ud fra dette grundsyn i hans salme erstattes derfor det fremadskuende »da« - med det »nu«, som brød igennem på alle felter i 1832 《.

Hvad man kan være uenig med Thaning om, er berettigelsen af at betragte alt dette som en ændring i selve kristendomssynet. I virkeligheden er der kun tale om en ændring i personlighedens indstilling, betinget af, at det, som før kun var »anskuelse«, nu tillige er $\gg$ liv «.

Omvendelsen fra det »højkirkelige« kirkesyn er f. eks. ikke en ændring i selve synet på kirken, men en ændring i indstillingen til kirken, som skyldes, at den fremadskridende kanalisering af barnetroen frigør personligheden fra den stærke bundethed til ydre autoriteter, i dette tilfælde trosbekendelsen og sakramenterne opfattet institutionelt så gudsforholdet bliver mere og mere direkte, hvorved der åbnes mulighed for en sekularisering af synet på det institutionelle ved kirken.

Den væsentlige betydning af Thanings værk er derfor ikke af teologisk, men af psykologisk karakter. 